\title{
INTERNATIONAL EXPERIENCES IN COOPERATIVE AUDIT AND LESSONS FOR SERBIA
}

\author{
Vladimir Zakić1, Marija Nikolić2, Vlado Kovačević3 \\ * Corresponding author Vladimir Zakić, zakic@agrif.bg.ac.rs
}

A R T I C LE I N F O

Review Article

Received: 15 December 2017

Accepted: 08 July 2018

doi:10.5937/ekoPolj1803111Z

UDC 657.6(4)(497.11)

Keywords:

cooperative audit, cooperatives, European experiences, Serbia

JEL: Q13, M49
A B S T R A C T

Basic characteristics of cooperative audit, its role in preservation of cooperative nature and promotion of cooperatives are analyzed in the paper. The aim of this paper is to propose measures to improve cooperative audit in Serbia based on the review of good practice in European countries.

The development stages of cooperative audit, from the creation of first cooperatives in Europe until today, have been examined using the historical method, with particular emphasis on the legislative framework that regulated this field. The comparative method was used to determine the differences between individual solutions, emphasizing their advantages and disadvantages, as well as the potential impact on the development of cooperatives.

The research suggests that there are different solutions, from the absence of cooperative audit, to its inclusion in the cooperative life cycle, starting from its establishment. Although legislative framework in Serbia foresee cooperative audit, this process needs to be significantly improved.

(C) 2018 EA. All rights reserved.

\section{Introduction}

The co-operative movement in Serbia evolved in parallel with the emergence of the first cooperatives in the world, going through various stages of ups and downs. Particularly critical stages in the development of cooperatives were in periods when cooperatives were used to achieve certain national, political and other goals, which resulted in the relinquishment of cooperative values and principles and the violation of the core identity of the cooperative. These disorders in cooperative practice resulted in a distortion of confidence in this form of organization of agricultural producers, linking

1 Vladimir Zakić, Ph.D., Associate professor, University of Belgrade, Faculty of Agriculture, Nemanjina Street no. 6, 11080 Zemun - Belgrade, Serbia, Phone: +381 114413 424, E-mail: zakic@agrif.bg.ac.rs

2 Marija Nikolić, Ph.D., Assistant professor, University of Belgrade, Faculty of Agriculture, Nemanjina Street no. 6, 11080 Zemun - Belgrade, Serbia, Phone: +381 114413 403, E-mail: mnikolic@agrif.bg.ac.rs

3 Vlado Kovačević, Ph.D., Assistant researcher, Institute for Agricultural Economics, Volgina 15, 11000 Belgrade, +38163554 414 E-mail: vlado.kovacevic@minpolj.gov.rs 
the term "cooperatives" with negative experiences and practices, which in the transition period had significantly slowed down the process of revitalization of the cooperative sector. In order to avoid such disorders and waiver of cooperative organizations from internationally accepted values and principles, it is important that cooperative audit is regularly implemented in practice.

The term audit represents a periodical control of the business of economic entities. All types of organizations implement some sort of auditing process. Having in mind that cooperatives distinguish from profit-oriented companies by its establishment, management, business, and objectives defined during its foundation, they require a special type of audit. Different terms are used to describe this process. The term cooperative audit is most common, but it is also referred as revision, control or verification. The term revision is used in the legislation of Austria (revision), Italy (revisione), France (révision) and some other countries, while in Slavic languages, including Serbian, the usual term is "revizija".

The cooperative audit is more than a pure financial audit and it looks at a wider set of indicators beyond business performance. One of the main tasks of cooperative audit is to verify compliance with cooperative values and principles, as well as with relevant legislation. Special emphasis in this process is given to the realisation of previously defined goals and particularly to cooperative management and implementation of decisions made by the general assembly, steering committee and supervisory board. That is why the cooperative audit is considered to be an efficient control mechanism which enables cooperative members to exercise their voting rights (Cracogna et al., 2013).

Co-operative audit is a prerequisite for a successful and vital cooperative system. In addition to the control role, the cooperative audit has an advisory role. It is especially significant in cooperatives with a large number of members, because a large membership cannot directly participate in the management of a cooperative, but it is realized through delegates. In such cases, in order to preserve the democratic nature of the cooperative, there is a need for the decision-making system to be transparent, which is controlled by a cooperative audit (Nikolić, 2009).

Cooperative audit needs to obey three principles: independence, credibility and usefulness (Spreckley, 2013). It must be reliable and carried out by an unbiased person, specifically trained for this task. The purpose of cooperative audit is not only to check previously achieved results, but also to help the management and members of a cooperative to improve decision-making processes and business performance in the future and to perform its business according to the cooperative principles.

There are two types of cooperative audit: internal and external. The internal audit is performed by one or a group of cooperative members, usually members of internal management body. In some countries independent experts can also be involved in internal cooperative audit. Their task is to check the financial aspect of business, and management reports, unless the cooperative is subject to external auditing (Cracogna et al., 2013). The external cooperative audit is the higher, second level. It is performed in regular time in- 
tervals, usually defined in legislation, and performed by external expert from cooperative union, private audit company, relevant government body or other similar institution.

The timely and regular audit of financial operations, the management and social standing of cooperatives' business is a precondition for a successful cooperative system (Henrÿ, 2012). European cooperative practice abounds in various solutions as to who conducts a cooperative audit, time intervals, reporting methods, procedures after the conducted audit, and the extent to which the adoption of proposed measures is mandatory.

As an exceptionally important factor in the development of the cooperative sector in Serbia, the emphasis should be on cooperative audit, primarily in terms of preventing misuse and manipulation. Restoration of trust in cooperatives, which was largely lost in the post-World War II period, cannot be achieved without a reliable and standardized system of cooperative audit (Zakić, Kovačević, 2015). By comparing the different experiences of European countries, the most important segments of the process of cooperative audit were identified in the paper, and based on this recommendations were made in order to improve this process in Serbia.

\section{Materials and methods}

The external cooperative audit, which is in the focus of this paper, is not in the spotlight of the literature. There is a lack of research on the practical relevance of cooperative audit, and of its relationship with the performance of cooperatives. However, cooperative audit is often considered in the highlight of the implementation of cooperative legislation. There are also several studies that pay certain attention to this topic. Main source of information presented in this paper were cooperative laws of different European countries and studies on their implementation in practice. When considering cooperative audit in Serbia, in addition to the current law on cooperatives, by-laws regulating this area were used, as well as papers written by local authors.

The basic methods used in the paper are: (1) the historical method, which was used to analyze the evolution of the application of cooperative audit in different socio-economic conditions; (2) the comparative method, which was used to identify similarities and differences in the application of cooperative audit in the European countries covered by the survey; and (3) the method of analysis and synthesis, which summarizes the results of the conducted research.

\section{Results and discussion}

Cooperative audit is more that pure financial audit, but they often go hand in hand. This is understandable, since cooperative audit often starts with the overview of financial documents. In some countries, the financial audit is the only form of control that cooperatives have to perform, and it usually contributes to a well-established system of control of cooperative work. In other countries, the cooperative audit is voluntarily and internal, which means that it is performed by a member of cooperative management, and the findings of such audit have advisory nature. However, many European countries practice external cooperative audit. 
International examples of cooperative legislation demonstrate different approaches on how the cooperative audit is regulated and carried out. The experiences of European countries related to cooperative audit can provide valuable insights and help countries with less developed cooperative sector to draw on lessons and explore best practices. Examples of countries where the cooperative audit is extensively regulated and institutionalised include Austria, France and Italy, but experiences of other countries, such as Poland and particularly Slovenia, can also be relevant for the case of Serbia.

\section{Cooperative audit in Austria}

The cooperative sector in Austria has a long tradition. Cooperative audit is compulsory and it was implemented from the early stages of the development of cooperative sector. Beside general Cooperative Law from 1873, last amended in 2006, there is special Law on Cooperative Audit from 1903, last amended in 2009.

One of the specifics of cooperative audit in Austria is that it is included in all the stages of cooperative life, stating from the registration procedure of cooperative as a form of initial audit. This means that every cooperative has to undergo a specific preliminary review exercised by an Auditing Association/Union (Revisionsverbände), from the moment of its establishment. The aim of this process is to confirm that a cooperative can permanently fulfil its mission in promoting its members.

After the preliminary review upon registration, cooperative audit is performed at least once every two financial years. The goal of these processes is to ascertain the compliance with cooperative legislation and statutes, appropriate activity and facilities, good accounting and management practices, and promotion of the interests of members in line with the cooperative's mission, statutes and agreements (Cracogna et al., 2013).

All cooperatives must be a member of an Audit Association. This organisation appoints an auditor that performs auditing process in all the cooperatives that are its members. The compulsory membership in Auditing Association has certain advantages and disadvantages. The advantage is that cooperative audit serves as a certificate to cooperative's members and its business partners that cooperative is doing well. On the other hand, other types of organizations or legal forms can choose an external auditor, while cooperatives are in unequal position (Kühl, 2012).

Only registered and licensed Associations and persons can act as auditors. The right to perform an audit is provided by the competent federal state authorities, usually the Ministry of Economic Affairs. All Audit Associations are member of The Association of Austrian Audit Associations (Vereinigung österreichischer Revisionsverbände) which is the roof organisation. Its task is to licence the auditors, which must pass an oral and written exam in order to gain a licence. This organisation also publishes the lists of licensed auditors, and regulates the professional principles that auditors should abide by in serving the public interest. 
The auditor appointed to carry out the cooperative audit has the right to examine the books and documents of the cooperative. After the audit, the auditor prepares a written report with comments on the financial situation and the cooperative's perspectives for development. According to the assumption of cooperative audit, the report also highlights the compliance with relevant legislation and the cooperative agreement, the promotion of the interests of members, performance and economic viability of the cooperative and the connections to other cooperatives.

If the auditor finds any irregularities in the work of cooperative, he/she reports to the Board of Directors and the Supervisory Board and they convene the General Assembly. There are no stated obligations, but the report contains strong recommendations on the improvement of the cooperative's work (Kühl, 2012). In the given timeframe, the cooperative initiate corrective measures. If not, the auditor can refer to the Audit Association/Union. If the irregularities are still present, the audit report can be submitted to the commercial register and referred to a court.

\section{Cooperative Audit in France}

The cooperative sector in France is one of the oldest in the world. Cooperatives are regulated by the general Law on cooperatives (1947), which is accompanied by legal documents for other types of cooperatives, such as so called Code Rural (1972) for agricultural cooperatives.

Cooperative audit has existed from the early days. From 1935, the cooperative audit has been carried out by a specially formed auditing union (Parker, Cowan, 1944). Today, cooperatives are submitted to the regular annual financial audit, like other types of organisation. In addition to that, cooperatives are obligated to perform cooperative audit, known as revision ( $f$ r. révision cooperative), once in five years. Cooperative audit covers the legal, management and governance aspects and serves to verify whether the organisation and function are in accordance to the principles and rules of a co-op, and in the interest of its members (COGECA, 2015). This is particularly important for agricultural cooperatives, since they are subject to strong verification mechanisms.

Like in Austria, cooperative audit is involved in co-op life from the beginning. The registration of cooperatives can be repealed on the basis of legal verification and check for consistency with compulsory principles.

Audit is performed by cooperative auditors. All auditors must have a licence, which is granted for a period of 5 years and cover one or several categories of cooperatives. License is provided by the Minister of Social Solidarity Economy, following consultation with the High Council for Cooperation (HCC). The HCC is an organisation that defines the principles and standards for cooperative revision, advises on matters concerning cooperation, such as draft legislation, and proposes measures to promote cooperatives' development. After the audit, auditor prepares a written report that should emphasis the accordance of statute with legal requirements and the adequacy of management practices. The report should be submitted to the management of the cooperative and cooperative members, and finally presented and discussed at the General Assembly. 
If the auditor finds any irregularities, he/she gives a deadline in which they should be corrected. If not, the matter will be forward to relevant Cooperative Union for a solution or even to a court ruling. If the irregularities persist, the final consequence of cooperative audit may even be the dissolution of the cooperative.

\section{Cooperative Audit in Italy}

Italian cooperative legislation is fragmentary and complex with provisions in several legal texts. All cooperatives should comply with the general rules of the Civil Code from 1942, last amended in 2003. The public control of cooperatives, known as revision (it. la revisione cooperativa), is regulated in the Legislative Decree of 2 August 2002. Besides the regular cooperative audit, cooperatives in Italy are subject to public control called "cooperative vigilance". ${ }^{4}$

The cooperative sector in Italy is developed and abounds in various types of cooperatives. There is a special emphasis on the social function of cooperatives, known as 'mutual purpose'. Cooperatives are considered to be mutual if they transact prevalently with their members. Other special laws stipulate that tax supportive measures apply only to mutual cooperatives (Bono, 2012).

Cooperatives in Italy are subject to both internal and external cooperative audit. Internal audit is performed by person from the management of cooperative (Cracogna et al., 2013).

External cooperative audit is more formal form of control usually carried out every two years and it refers to "mutual nature" of the cooperative. The audit should demonstrate that co-op is organised and functioning in line with the legislation and the rules of procedure adopted by the cooperative. It takes into consideration the effectiveness of membership, member participation in cooperative management, mutual relations and distribution of profit, tests eligibility of cooperative for tax and other benefits. Beside regular cooperative audit, extraordinary control may be carried out at any time, and it is initiated by the Ministry of Economic Development.

The cooperatives in Italy have strong incentives to federate. The cooperative audit is performed by the cooperative associations or federations towards their members (and to the cooperatives that have paid biannual contribution to this organisation) and by the Ministry of Economic for those cooperatives that are not members of any association.

The findings of the audit are documented in a report. If the auditor finds any irregularities, the cooperatives should correct them. The Ministry can take different measures if corrections weren't executed. These measures range from the substitution of the members of the cooperative organs with a director designated by the Ministry, to the most radical, dissolution of the cooperative (Cracogna et al., 2013).

4 http://www.parlamento.it/parlam/leggi/deleghe/02220dl.htm

The case study is mostly based on an overview of the relevant legislation. 


\section{Cooperative Audit in Poland}

The Polish cooperative movement also has a long tradition. Cooperatives are regulated by general Cooperative Law Act $(1982)^{5}$. Although this law was amended many times in the transition period, cooperative sector did not reach its full potential.

The cooperatives in Poland practise internal and external cooperative audit. Internal audit is performed by cooperatives' internal Supervisory Council which is composed of at least three members elected by the General Assembly. The responsibilities of this body related to cooperative audit include examining periodic reports and financial statements, carrying out periodic assessments of cooperative performance, with emphasis on members' rights, and carrying out control functions.

External cooperative audit ('lustracja' in Polish) is compulsory and conducted every three years. Besides controlling role, external audit also has a support and advisory function for cooperatives. The aim of audit is to: 1) verify compliance with the law and statute; 2 ) examine whether activities support the interests of members; 3 ) confirm effectiveness of the pursuit of economic, social and cultural principles; 4) notify cooperative members of any irregularities in its management; and 5) provide guidance to help address identified irregularities, improve functioning and support cooperative development.

External cooperative audit can be performed by cooperative union or association, or by The National Cooperatives Council (NCC). Cooperative Associations were present in the Polish cooperative movement since the foundation of the first cooperatives and carried out both business and non-economic functions (Parker, Cowan, 1944). Cooperative unions and association operate at country level and in all sectors and carry out cooperative audit, but membership is not obligatory. According to the Law on cooperatives (1961) co-ops had to be members of Auditing Cooperative Union, but this obligation was cancelled in 1985. Since the membership in Auditing Cooperative Unions is voluntarily, this results in a large number of unions that can carry out the cooperative audit (Matczak, 2012).

The National Cooperatives Council (NCC) manages the auditing rights of cooperative associations and issues licenses to auditors. Besides that, NCC also: a) represents cooperatives towards the government and in front of state authorities; b) act effectively in the legislative process; c) organizes research, training and information activities; d) keeps a register of cooperative audits; e) organizes arbitration procedures in the case of disputes between cooperatives, and if that is not successful requests that conflicts are resolved through court; and f) perform the audit of unions and associations of cooperatives.

The auditor prepares a report after the audit and submits it to the cooperative's Supervisory Council and Management Board. The findings of the audit are discussed at the next General Assembly meeting. The report serves as an official document and contains recommendations related to the improvement of cooperative business.

5 http://isap.sejm.gov.pl/DetailsServlet?id=WDU19820300210

The case study is partially based on an overview of this legislation.

http://ea.bg.ac.rs 


\section{Cooperative Audit in Slovenia}

After the independence, the Law on Cooperatives was adopted in Slovenia in 1992. This law introduced the compulsory cooperative audit for all cooperatives.

The Law on Cooperatives were amended in 2007, including the chapter on cooperative audit, with detailed provisions on the content and scope of the audit. The legislation anticipated that the Cooperative Union should audit all its members and that all cooperatives with indivisible assets must become members of this Union within a specified period of time (Avsec, Modic, 2008).

However, these changes in cooperative law were interpreted in specific manner. The Slovenian authorities took a view that a cooperative union cannot be considered independent from the cooperatives that are its members, and therefore does not meet the criteria for conducting cooperative audit. In 2009 a change of cooperative law was adopted, which deleted the provisions on cooperative audit and eliminated the compulsory union membership for cooperatives with indivisible assets, making membership for all cooperatives voluntary (Avsec, Žerjav, 2010).

In the following years there were initiatives for the reintroduction of the cooperative audit, including a draft law in 2010, but the cooperative audit has not been re-established in Slovenia.

\section{Cooperative Audit in Serbia}

The cooperative sector in Serbia has a long tradition and has developed in parallel with the European and world cooperatives. Just two years after the establishment of the Rochdale cooperative in the UK, in 1846, first agricultural credit cooperative "Gazdovský Spolok" in Bački Petrovac was established. On the territory of Serbia from that period (without Vojvodina) first cooperatives were established in 1894.

Along with the development of the cooperative sector, considerable attention was paid to cooperative auditing. In the early cooperatives, a specific form of internal audit was practiced through the so-called "court of good people", although its activity was mainly aimed at resolving possible disputes and prescribing the character features of the cooperative members. However, the importance of cooperative audit was recognized in the first law regulating the work of cooperatives in Serbia - Law on agricultural and handicraft cooperatives (1898). This law regulated the establishment and operation of cooperative associations, in which membership was compulsory and who performed the tasks of cooperative audit. Cooperative audit was also included in the following Law on economic cooperatives from 1937.

Until the World War II, cooperative movement went through different phases, but most of the consequences for the contemporary situation in the cooperative sector were the developmental forms of cooperatives after 1945. Establishment of Peasant Producer Cooperatives, which practiced obligatory membership and investment of land, cattle and other agricultural inputs, and later of General Agricultural Cooperatives where business practice was not in line with the cooperative principles widely recognised 
today, contributed to the negative connotation and lose of confidence in cooperatives. Existence of socially-owned property in cooperatives has roots from the period after economic reforms in 1965, and particularly from 1970's when agricultural cooperatives where merged with agricultural companies.

In the transition period, the cooperative audit was re-established in the Law on Cooperatives, adopted in 1996, but its implementation was limited, which had some undesirable consequences. For example, in this period there were number of organisation that used the name "cooperative" although did not have much in common with true co-ops. These organisations also apply a lot of damage to the idea of cooperatives. The irregular implementation of the cooperative audit, as well as its limited effects, enabled such behaviour (Nikolić, Arsenijević, 2015).

Currently cooperative sector is regulated by The Law on Cooperatives, adopted at the end of 2015. According to this law (Article 80), the "cooperative audit is control of the harmonization of business, management and organization of the cooperative with the provisions of this Act, cooperative principles and cooperative values".

There is distinction between cooperative audit and the audit of financial statements, according to the Law on Cooperatives (2015). In Article 57 is stated that a cooperative must keep business books, and draw up and submit financial statements in a manner and under conditions prescribed by the law governing accounting. The audit of the cooperative's financial statements is performed in accordance with the law governing the audit. ${ }^{6}$

The cooperative audit in Serbia is compulsory for all cooperatives and may be regular and extraordinary. Regular cooperative audit is conducted every two years at the request of the cooperative. An extraordinary cooperative audit is carried out if necessary at the request of: any governance body of the cooperative, at least 50 members of the cooperative, at least 30 percent of its members if the cooperative rules do not set a higher number of cooperative members, the cooperative union of which the cooperative is a member, the competent ministries, and creditors of the cooperative (Article 82, paragraph 3).

Law on cooperatives (2015), like the previous law from 1996, only superficially covers the area of cooperative audit, following the idea that more precise guidelines will be given in bylaws, created and adopted by auditing unions. Since several unions can be licensed to perform cooperative audit, this imply that bylaws can differentiate among themselves. In practice, this was the case during 1990s, when there were several Regulations, adopted by the Cooperative Union of Yugoslavia and the Union of Youth and Student Cooperatives of Yugoslavia. ${ }^{7}$ Despite some similarities, these regulations had some substantially

6 Law on Accounting (“Off. Gazette of RS”, no. 62/2013) and Law on Audit (“Off. Gazette of RS", no. 62/2013).

7 For example, Cooperative Unions during the 1990s individually wrote and adopted at least two partially different regulations: (1) The Rules on Cooperative Audit of Cooperative Union of Yugoslavia ("Sl. list SRJ" no. 26/98 and 28/98 - corr. and "Sl. list SCG" no. 1/2003 Constitutional Charter), and (2) The Rules on Cooperative Audit of Union of Youth and Student Cooperatives of Yugoslavia ("Sl. list SRJ" no. 21 of 24 April 1998; 65/99 and 7/2000) 
differences. Finally, this resulted in a situation where the process of cooperative audit is performed differently depending on the membership in cooperative unions.

All these inconsistency contributed to the fact that in the past the cooperative audit was carried out inadequately in Serbia.

\section{Recommendations for improving Serbia's experience based on international examples}

The examples of good practices and the experiences of other countries offer insights that might help in creation of a suitable model of cooperative audit for Serbia. A precondition for the successful implementation of cooperative audit is that audit unions lead the process efficiently and uniformly.

One of the first obstacles in this process is the unwillingness of cooperatives to became members and fully participate in the work of unions. The Polish experience indicates that one of the possible solutions is to establish some other form of organization that would perform cooperative audit in those cooperatives that are not member of any union. If insisted that only unions have the power to perform cooperative audit, an obligatory membership in auditing unions can be prescribed, as in Austria.

Another important factor is that the cooperative audit is subject to the same rules and procedures for the entire territory of the Republic of Serbia, as is done in many other European countries. In order to help the process of harmonization, the Ministry produced a model/template of the Rulebook and published it on its website. However, this document was just a guideline and had no compulsory nature, so it was left to every Audit Union if it chooses to amend and adjust it in accordance with their individual needs. Currently (end of 2017), there are four unions that are authorized to perform cooperative audits in Serbia: Cooperative Union of Serbia, Cooperative Union of Vojvodina, Cooperative Union of Belgrade, and Student and Youth Cooperative Union of Serbia. In practice, all four authorized Audit Unions adopted the Rulebook model unchanged, yet this does not guarantee its uniform implementation.

Having in mind previously elaborated experiences of chosen EU countries, the list of recommendation for improving the process of cooperatives audit in Serbia has been created. These activities may contribute to the modernization of the process of cooperative audit, which would consequently have positive effect on cooperative sector in total.

First, legislative framework needs to be supplemented with a procedure for issuing a certificate or license for cooperative auditors and to adopt criteria for acquiring the certificate, additional to those listed in the Law.

Second, in order to gain the license, auditors should take an auditors' exam after attending a specific education programme for auditors. Even after issuing the license, auditors would be under the obligation to attend additional courses in order to raise the competence, qualifications and quality of their work and to reapply for the license. 
Third, it is also practice to publish a Register of Cooperative Auditors in the country. It would be advised that such register is published by the competent Ministry or Serbia's Ministry of Economy. All auditing unions can also publish separate registers of auditors for their members, but the Ministry can consolidate these information in a national Register of Cooperative Auditors, uniform for the whole territory of Serbia.

Fourth, according to the experience of France, Italy, Poland and other countries, it is also recommended to predict a withdrawal of the auditors' license of certificate in the case of misconduct. This would improve the accountability in the work of cooperative auditors and contribute that cooperative audit is performed in accordance with its principles.

In the end it is necessary to underline one more time the importance of adopting the same procedures and rules for the entire territory of the Republic of Serbia.

\section{Conclusions}

Further development of the cooperative audit system can be achieved through efforts to start introducing uniformity and standardization of the criteria for acquiring the cooperative auditor's certificate, as well as for the procedure and method of performing cooperative audit. For now, this cannot be achieved in a legally binding way on the level of the country because the Law doesn't foresee adoption of the bylaws on the national level, but initial steps can be taken so that every Audit Union applies the same criteria when hiring its own auditors or performing cooperative audit.

Also, the possibility of Audit Union's voluntary cooperation with other licensed Audit Unions in the Republic of Serbia on the standardisation of cooperative audit should be noted and encouraged.

Only through the continuous further development the cooperative audit system in Serbia will be able to fulfil goals proclaimed by the Serbia's Law on Cooperatives, i.e. support the practical use of cooperative audit reports, controlling and improving the work of cooperatives, and the potential future realization of the rights to subsidies, tax relief and other benefits envisaged by the Law.

\section{Acknowledgements}

The paper is part of the research within the project no. 179028 - Rural labour market and rural economy of Serbia - Diversification of income and poverty reduction, financed by the Ministry of Education, Science and Technological Development of the Republic of Serbia.

The paper is part of the research within the project FAO/EBRD Technical Cooperation project "Supporting the Development of Agricultural Cooperatives in Serbia" Recommendations for a Uniform and Effective Cooperative Audit System in Serbia.

\section{Conflict of interests}

The authors declare no conflict of interest. 


\section{References}

1. Avsec F., Modic, D. (2008). Cooperative auditing in Slovenia: a brief survey of the past and the present regulations. World congress of accounting historians (WCAH): program and abstracts, pp. 1329-1337.

2. Avsec, F., Žerjav, P. (2010). European Cooperative Society and Recent Developments of Cooperative Legislation in Slovenia. Retrieved from http://www.cressrhone-alpes.org/cress/IMG/pdf/Avsec_Czerjav_pap.pdf (March 17, 2017).

3. Bono, P. (2012). Support for Farmers' Cooperatives; Country Report Italy. Wageningen: Wageningen UR, Netherlands.

4. Comité Général de la Coopération Agricole - COGECA (2015). Development of Agricultural Cooperatives in EU, 2014. European Agri-Cooperatives, Brussels. Retrieved from http://zadruge.coop/upload_data/site files/development-of-agricultural-cooperatives-in-the-eu_2014.pdf (March 15, 2017).

5. Cracogna, D., Fici, A., Henrÿ, H., eds. (2013). International Handbook of Cooperative Law, Springer \& Euricse, New York, USA.

6. Henrÿ, H. (2012). Guidelines for Cooperative Legislation, third, revised edition. International Labour Office, Geneva, Switzerland.

7. Kühl, R. (2012). Support for Farmers' Cooperatives; Country Report Austria. Wageningen, Wageningen UR, Netherlands.

8. Matczak, P. (2012). Support for Farmers' Cooperatives; Country Report Poland. Wageningen: Wageningen UR.

9. Nikolić, M. (2009). Evolution of cooperative legislation in Europe. Serbian Association of Agricultural Economists, Belgrade, Serbia. [in Serbian: Николић, М. (2009), Еволуција задружног законодавства у Европи].

10. Nikolić, M., Arsenijević, J. (2015). Comparison of the laws on cooperatives in the Republic of Serbia and its neighboring countries, LIMEN 2015, Leadership and management - state, company, entrepreneur, Belgrade, Serbia, 241-249. [in Serbian: Николић, М., Арсенијевић, J. (2015), Компарација закона о задругама у Републици Србији и земљама у окружењу].

11. Parker, F., Cowan, H. (1944). Cooperative Associations in Europe and Their Possibilities for Post-War Reconstruction. United States Department of Labor, Bureau of Labor Statistics, Bulletin No. 770, Washington, D. C, USA.

12. Spreckley, F. (2013). Co-operative Accounting and Audit Toolkit. Local Livelihoods, Herefordshire, UK.

13. Zakić, V., Kovačević, V. (2015). Significance of cooperative audit for the cooperative sector in Serbia. Revizor 18(72), 79-89. [in Serbian: Закић, В., Ковачевић, В. (2015), Значај задружне ревизије за развој задружног сектора у Србији]. 